\title{
Concentration of human milk immunoglobulins by ultrafiltration
}

\author{
S Mahé 1, S Aubry 2, V Barrois-Larouzé 2, \\ A Pierre 3 , D Tomé 1 \\ ${ }^{1}$ INRA, Laboratoire de Nutrition Humaine et Physiologie Intestinale, \\ UER des Sciences Pharmaceutiques et Biologiques, 4, avenue de l'Observatoire, 75006 Paris; \\ 2 Institut de Puériculture, Lactarium, 26 boulevard Brune, 75014 Paris; \\ ${ }^{3}$ INRA, Laboratoire de Recherches de Technologie Laitière, 65 rue de Saint-Brieuc, \\ 35042 Rennes Cedex, France
}

(Received 1 August 1990; accepted 26 December 1990)

\begin{abstract}
Summary - Immunoglobulin fractions have been successfully used in vivo for the treatment of illnesses such as chronic diarrhea in the newborn. When used to fortify human breast milk, it is important that the milk immunoglobulins remain unaltered during the protein concentration process. The purpose of the present study was to evaluate changes in the quantity of IgA, IgG and IgM immunoglobulins after concentration of human milk proteins by an ultrafiltration membrane technique. Immunoglobulins present in human milk and the retentate obtained after ultrafiltration of the milk were analyzed by ELISA and gel filtration. The recovery of immunoglobulins in the retentate obtained from ultrafiltration was high: $100 \%, 70 \%$ and $60 \%$ of the total $\operatorname{lgA}$, $\lg$ G and $\operatorname{lgM}$, respectively. ELISA showed that $\operatorname{lgA}$ was the major immunoglobulin present in human milk. Gel filtration analysis showed that the $\lg A$ immunoglobulins were entirely in the form of dimeric secretory $\lg A$ s both in the milk and in the retentate. Ultrafiltration appears to be a useful technique for preparing immunoglobulin-enriched human milk fractions.
\end{abstract}

\section{ultrafiltration / human milk / immunoglobulins}

Résumé - Concentration, par ultrafiltration, des immunoglobulines dans le lait humain. Les immunoglobulines du lait humain ont été utilisées avec succès comme traitement de certaines pathologies chez le nouveau-né. Le travail présenté dans ce manuscrit a été entrepris pour suivre les concentrations en immunoglobulines dans un lait humain au cours d'une ultrafiltration qui a pour but de concentrer la fraction protéique du lait. Les immunoglobulines présentes dans le lait humain et dans le rétentat obtenu par ultrafiltration sont dosées par une technique ELISA avant et après chromatographie en gel filtration. Les proportions des immunoglobulines retrouvées dans le rétentat après ultrafiltration sont respectivement de $100 \%$, $70 \%$ et $60 \%$ des $\lg A$, $\lg$ G et $\lg M$ totales du lait de départ. Le dosage ELISA montre que les $\operatorname{lgA}(0,274 \pm 0,04 \mathrm{~g} / \mathrm{kg})$ sont les immunoglobulines majoritaires dans le lait humain. Les chromatographies en gel filtration révèlent que les lgA du lait et du rétentat sont sous forme dimérique (IgA sécrétoires). L'ultrafiltration, qui ne détruit pas les immunoglobulines du lait, semble donc une bonne technique pour préparer des fractions de lait humain enrichi en immunoglobulines.

\section{ultrafiltration / lait humain / immunoglobulines}




\section{INTRODUCTION}

Human milk is still considered to be the best tolerated form of milk for the newborn infant (Ogra and Greene, 1982), but is nutritionally inadequate for the very low birthweight neonate who requires more protein than is available in human breast milk for the catch-up growth phase characteristic of these infants. For this reason, human milk protein concentrates have been developed for the fortification of breast milk (Lucas et al, 1980; Voyer et al, 1984). Human milk is also known to contain protective factors against infection and disease in the newborn (Pitt, 1979), including immunoglobulins. For example, a bacteriostatic effect of milk protein fractions fortified in secretory immunoglobulin $\mathrm{A}$ and/or lactoferrin has been demonstrated in vitro (Bullen et al, 1972; Spik et al, 1978; Arnold et al, 1980). Such protein fractions have also been used with success in vivo in the treatment of neonatal diarrhea (Navarro et al, 1983; Spik et al, 1984).

Therefore, it is possible that fortifying human breast milk with human milk protein fractions could not only be useful in the neonatal unit for the feeding of very low birthweight neonates, but also in gastroenterology and pediatric surgery units where it could serve as a potential therapeutic aid. In regard to the latter, it is important that the milk immunoglobulins remain unaltered after protein concentration. The purpose of the present study was to evaluate changes in the quantity of immunoglobulins $A, G$ and $M(\lg A, \lg G, \lg M)$ after concentration of human milk proteins by an ultrafiltration membrane technique (Maubois and Brulé, 1982; Maubois, 1984).

\section{MATERIALS AND METHODS}

\section{Milk collection and ultrafiltration}

Raw pooled human milk (RPM), provided by the Lactarium de Lille (Lille, France), was collected from healthy mothers. The milk was kept frozen at $-18^{\circ} \mathrm{C}$ up until the time of use at which point $313.8 \mathrm{~kg}$ was thawed, skimmed and ultrafiltrated (fig 1) in the Laboratoire de Recherches de Technologie Laitière (INRA, Rennes, France) according to the technique of Maynard et al (1989). Thirty-six kg of retentate was obtained from the ultrafiltration.

After 2 successive centrifugations of the RPM $\left(1600 \mathrm{~g}, 4^{\circ} \mathrm{C}, 30 \mathrm{~min}\right)$, the fat layer was removed. The defatted RPM and retentate were then ultracentrifuged at $100000 \mathrm{~g}$ for $2 \mathrm{~h}$ at $4{ }^{\circ} \mathrm{C}$. The supernatants were aspirated and aliquoted, whereas the pellets (which contain casein) were discarded. The total immunoglobulin response was quantitatively recovered in the supernatant according to ELISA.

\section{Fast protein liquid chromatography}

Fast protein liquid chromatography (FPLC) was performed with an LCC 500 system (Pharmacia, Saint-Quentin-en-Yvelines, France) equipped with a Superose 12 (Pharmacia) gel filtration column and a UV detector set at a wavelength of $280 \mathrm{~nm}$. The column was eluted with a $50 \mathrm{mM}$ PBS buffer ( $\mathrm{pH} \mathrm{7.0)}$ at a flow rate of $0.4 \mathrm{ml} / \mathrm{min}$. After filtration through a $0.22-\mu \mathrm{m}$ filter, $200 \mu \mathrm{l}$ of each sample were injected into the column and the eluent was collected in $0.8-\mathrm{ml}$ fractions.

\section{Enzyme linked immunosorbent assay (ELISA)}

For the ELISA of $\lg A$, IgG and IgM, microtiter plates for micro-ELISA (Nunc) were used as the 


\section{MILK PREPARATION}

\section{RA. W 500 I.}

$(313.8 \mathrm{~kg})$

skimming

Creamer Westfalia

$48-50^{\circ} \mathrm{C}$

\section{2x Romicon PM $502.45 \mathrm{~m}^{3}$}

\section{Centrifuge pump $15 \mathrm{~m}^{3}$}

$2 \mathrm{H} 50^{\circ} \mathrm{C}$

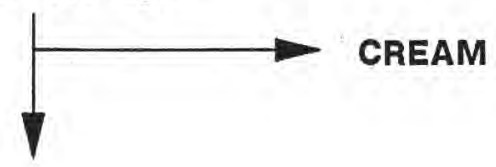

SKIMMED MILK

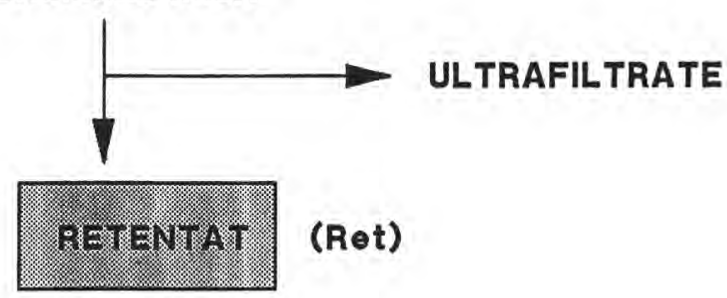

$(36 \mathrm{~kg})$

Fig 1. Preparation of $36 \mathrm{~kg}$ retentate from $313.8 \mathrm{~kg}$ raw pooled milk by the ultrafiltration technique.

Schéma de préparation de $36 \mathrm{~kg}$ de rétentat obtenu par ultrafiltration de $313,8 \mathrm{~kg}$ d'un mélange de lait cru humain (RPM).

solid-phase carrier. Goat antibody anti-human IgG (Biosys), anti-human IgM (Miles) and antihuman IgA (Behring) were applied at $100 \mu \mathrm{l} /$ well in a coupling buffer $(60 \mathrm{mM}$ bicarbonate buffer, $\mathrm{pH} 9.8$ ) at dilutions of $1 / 2000,1 / 1500$, and $1 /$ 2000 , respectively. After an overnight incubation at $4^{\circ} \mathrm{C}$, plates were washed in PBS-Tween buffer (phosphate-buffered saline, $\mathrm{pH} 7.4$, containing $0.05 \%$ Tween 20 ). Test samples were then incubated in duplicate in $100 \mu \mathrm{l} /$ well PBSTween at $37^{\circ} \mathrm{C}$ for $90 \mathrm{~min}$. After washing with PBS-Tween buffer, plates were incubated with goat antibody peroxidase conjugate $(100 \mu \mathrm{l} /$ well) at $37^{\circ} \mathrm{C}$ for $1 \mathrm{~h}$ more. Anti-lgA (Biosys), anti-lgG (Biosys) and anti-IgM (Miles) were previously diluted in PBS-Tween at dilutions of $1 / 3000,1 /$ 6000 and $1 / 4000$, respectively. After the final wash, peroxidase activity was detected with 100 $\mu \mathrm{l} /$ well orthophenylenediamine substrate (Prola- bo) freshly dissolved at $0.4 \mathrm{mg} / \mathrm{ml}$ in citrate buffer $(50 \mathrm{mM}, \mathrm{pH} 5.0)$. After $15 \mathrm{~min}$, the reaction was stopped by addition of $5 \mathrm{~N}$ sulfuric acid $(50 \mu \mathrm{l} /$ well), and quantified by measurement of absorbance at a wavelength of $490 \mathrm{~nm}$ on a microplate autoreader (Bio-Tek instrument). Standard curves for $\lg A$, $\lg M$ and $\lg G$ were established with a standard (Behring, RueilMalmaison, France).

\section{RESULTS AND DISCUSSION}

The concentration of $\lg G, \lg M$ and $\lg A$ was measured by ELISA both in the RPM and the retentate obtained after ultrafiltration (table I). IgA was the major immunoglobu- 
Table I. IgG, IgM, and IgA ELISA measurements in the raw pooled human milk (RPM) and retentate after ultrafiltration $(n=6)$.

Détermination des IgG, IgM et IgA par technique ELISA dans un lait humain (RPM) et son rétentat obtenu par ultrafiltration $(\mathrm{n}=6)$.

\begin{tabular}{lcccc}
\hline & $\begin{array}{c}\text { Raw pooled } \\
\text { milk }\end{array}$ & Retentate & $\begin{array}{c}\text { Concentration } \\
\text { yield }\end{array}$ & $\begin{array}{c}\text { Total } \\
\text { recovery }(\%)\end{array}$ \\
\hline Total weight $(\mathrm{kg})$ & 313.8 & 36 & - & - \\
$N \times 6.38^{\mathrm{a}}(\mathrm{g} / \mathrm{kg})$ & 14.56 & 63.75 & 4.4 & 50.2 \\
$\operatorname{lgG}^{\mathrm{b}}(\mathrm{g} / \mathrm{kg})$ & $0.024 \pm 0.0008$ & $0.147 \pm 0.019$ & 6.1 & 69.8 \\
$\operatorname{lgM}^{\mathrm{b}}(\mathrm{g} / \mathrm{kg})$ & $0.012 \pm 0.0006$ & $0.061 \pm 0.002$ & 4.9 & 58.3 \\
$\lg \mathrm{A}^{\mathrm{b}}(\mathrm{g} / \mathrm{kg})$ & $0.274 \pm 0.043$ & $2.46 \pm 0.23$ & 8.9 & 100 \\
\hline
\end{tabular}

a Total nitrogen content was determined by the micro-Kjeldahl technique (Hambraeus et al, 1976). ${ }^{\circ}$ ELISA measurements in samples after ultracentrifugation of RPM and retentate.

lin present in the human breast milk. After ultrafiltration, the Ig fractions remained in the retentate with a 5-9 concentration yield relative to the RPM. Furthermore, 100,70 and $60 \%$ of the total $\lg A, \lg G$ and $\lg \mathrm{M}$ respectively was recovered in the retentate.

Chromatography of the supernatants obtained from the ultracentrifugation of RPM and of the retentate was performed by gel filtration (figs 2,3 ). In order to differentiate dimeric secretory $\lg A(\lg A s)$ from monomeric $\lg A$, the collected fractions were analysed by ELISA. A standard serum (Behring), which contained both monomeric $\lg \mathrm{A}(160000 \mathrm{Da}$ ) that eluted at 8.8 $\mathrm{ml}$ and dimeric secretory $\lg \mathrm{A}(420000 \mathrm{Da}$ ) that eluted at $4.8 \mathrm{ml}$, was used as the standard (fig 2A). Under the same conditions, IgA ELISA monitoring of the gel filtration fractions from RPM (fig $2 \mathrm{~B}$ ) and retentate (fig 2C) showed only one peak of $\mathrm{IgAs}$ eluted at $4.8 \mathrm{ml}$. Monitoring of RPM and retentate at an absorbance of $280 \mathrm{~nm}$ indicated a major peak of $\alpha$-lactalbumin
(14 $000 \mathrm{Da}$ ) eluted at $12 \mathrm{ml}$. IgG and $\lg M$ ELISA monitoring of the gel filtration fractions indicated that both $\lg G$ and $\lg M$ were eluted in single peaks at $10 \mathrm{ml}$ and $6 \mathrm{ml}$, respectively, in the raw pooled milk (fig $3 A$ ) and retentate (fig $3 \mathrm{~B}$ ).

The current work confirms that $\lg A$ is the major $\mathrm{Ig}$ in human milk and is present entirely in a dimeric secretory form (Hanson et al, 1973; McClelland, 1982; Woodhouse et al, 1988). A significant amount of the $\mathrm{lg}$ fraction of human milk can be recovered in the retentate obtained after ultrafiltration of the milk. $\lg A$ is recovered most efficiently from the retentate where it remains in its dimeric secretory form. These results indicate that ultrafiltration could be a useful technique for the preparation of Ig-enriched milk fractions. However, the conditions allowing efficient sterilization of such a product without alteration of the $\mathrm{lg}$ fraction need to be established before it can be used as a therapeutic aid in the treatment of illness in very low birthweight neonates. 

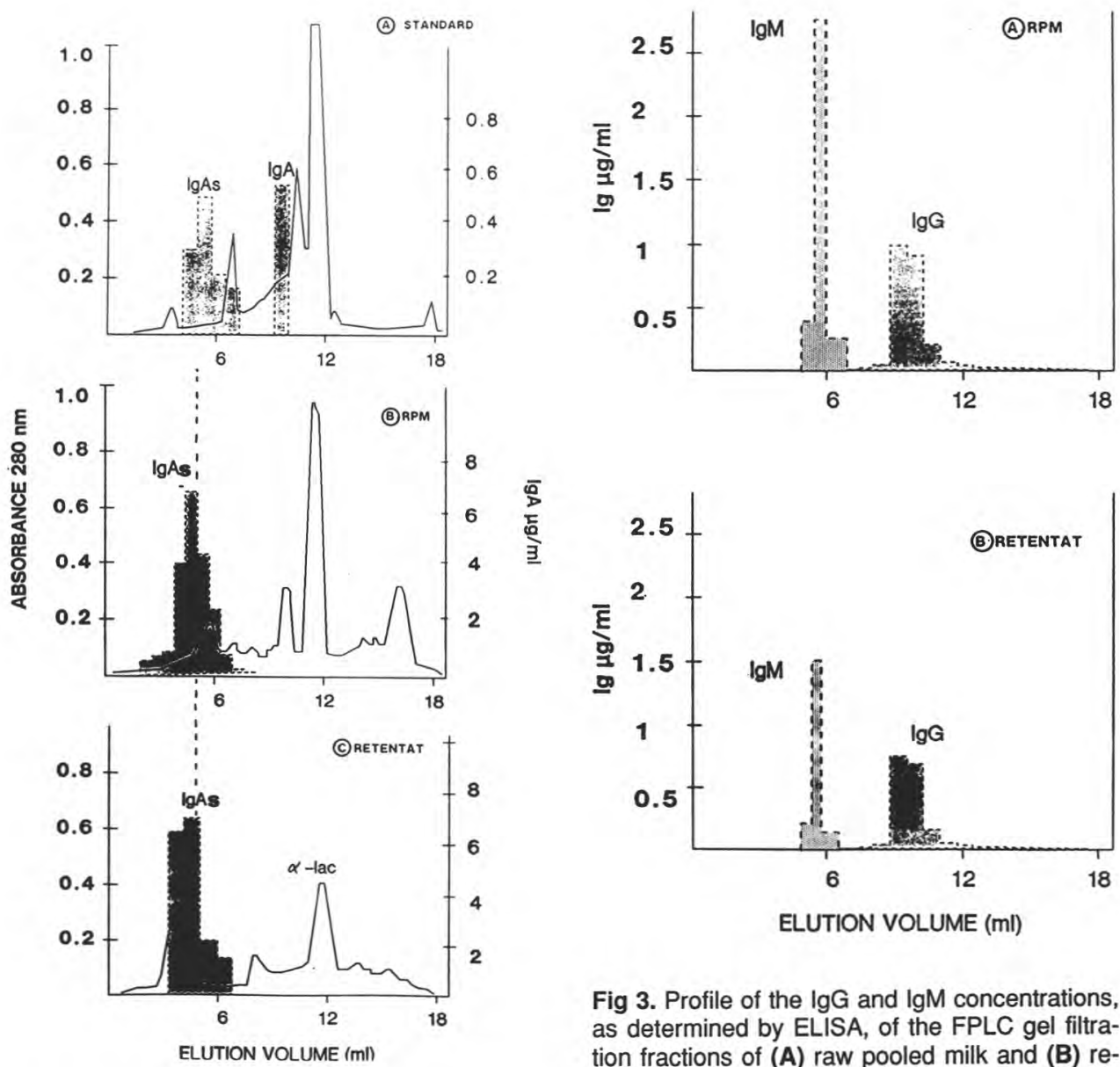

Fig 2. Profile of the $\lg A$ concentrations $(---)$, as determined by ELISA, of the FPLC gel filtration fractions of (A) standard, (B) raw pooled milk and $(C)$ retentate on Superose $12(-)$. In comparison to the standard in which there were 2 forms of $\lg A$ (monomeric and dimeric), only dimeric $\lg A(\lg A s)$ was found in the RPM and retentate samples.

Profil des concentrations en $\lg A(---)$ dosées par technique ELISA après chromatographie FPLC sur colonne Superose 12 (-) d'un témoin standard $(A)$, du lait cru $(B)$ et du rétentat $(C)$. $D$ 'après le profil standard $(A)$, on ne retrouve que des IgA de sécrétion dans le lait cru (RPM) et le rétentat.

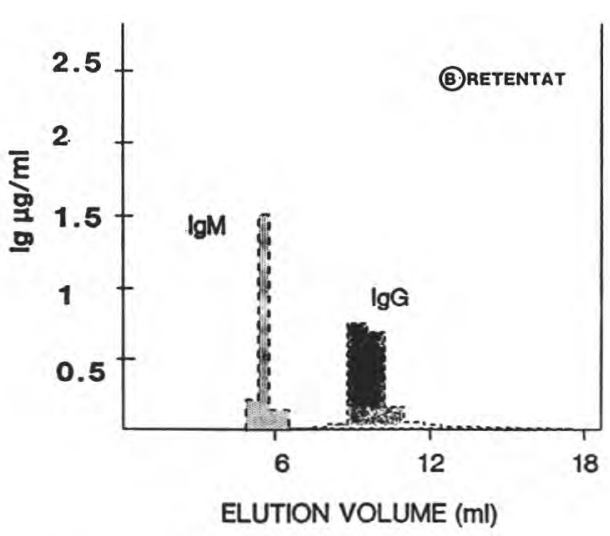

Fig 3. Profile of the $\lg G$ and $\lg M$ concentrations, as determined by ELISA, of the FPLC gel filtration fractions of $(A)$ raw pooled milk and $(B)$ retentation Superose 12.

Profil des concentrations en $\lg G$ et $\lg M$ dosées par technique ELISA après chromatographie FPLC sur colonne Superose 12 du lait cru (A) et du rétentat $(B)$.

\section{ACKNOWLEGMENTS}

This work was supported in part by grants from the French Department of Research and Technology. We would like to thank $L$ Trebler Winters for her help in improving the English of the manuscript. 


\section{REFERENCES}

Arnold RR, Brewer M, Gauthier JJ (1980) Bactericidal activity of human lactoferrin: sensitivity of a variety of microorganism. Infect $\mathrm{Im}$ mun 28, 893-898

Bullen JJ, Rogers HJ, Leigh L (1972) Ironbinding proteins in milk and resistance to $E s$ cherichia coli infection in infants. $\mathrm{Br}$ Med $\mathrm{J} 1$, 69-72

Hambraeus L, Forsum E, Abrahamsson L, Lonnerdal B (1976) Automatic total nitrogen analysis in nutritional evaluation using a block digestor. Anal Biochem 72, 78-85

Hanson LA, Motas C, Barrett J (1973) Studies of the main immunoglobulin of human milk: secretory IgA. In: Immunology of Reproduction. Bulgarian Academy Science Press, Sofia, 687-692

Lucas A, Lucas PJ, Chavin St, Lyster RLJ, Baum JD (1980) A human milk formula. Early Hum Dev 4, 15-21

Maubois JL (1984) Separation, extraction and fractionation of milk proteins components. Lait 64, 485-495

Maubois JL, Brulé G (1982) Utilisation des techniques à membrane pour la séparation, la purification et la fragmentation des protéines laitières. Lait 62, 484-510

Maynard F, Pierre A, Maubois JL (1989) Procédé de fractionnement des protéines du lait humain, conduisant à la production, notamment de lactoferrine et d' $\alpha$-lactalbumine. French patent No 2631785
McClelland DBL (1982) Antibodies in milk. J Reprod Fertil 65, 687-692

Navarro J, Lambert-Zechousky N, Cezard JP (1983) Alimentation et écosystème bactérien intestinal en pathologie digestive pédiatrique. Arch Fr Pédiatr 40, 677-679

Ogra PL, Greene HL (1982) Human milk and breastfeeding: an update on the state of the art. Pediatr Res 16, 266-271

Pitt J (1979) Breast milk and the high-risk baby: potential benefits and hazards. Hosp Pract $14,81-86$

Spik G, Cheron A, Montreuil J, Dolby JM (1978) Bacteriostasis of a milk sensitive strain of Escherichia coli by immunoglobulins and ironbinding proteins in association. Immunology 35, 663-671

Spik G, Jorieux S, Mazurier J, Navarro J, Romond C, Montreuil J (1984) Characterization and biological role of human lactotransferrin complexes. In: Human Milk Banking (Williams AF, Baum JD, eds) Raven Press, New York, Nestlé Nutrition Workshop Ser 5, 133143

Voyer M, Senterre J, Rigo J, Charlas J, Satge P (1984) Lactoengineéring. Human milk lactoengineering: growth, nitrogen metabolism and energy balance in preterm infants. Acta Paediatr Scand 73, 302-306

Woodhouse LR, Lonnerdal MS, Lonnerdal B (1988) Quantitation of the major whey proteins in human milk, and development of a technique to isolate minor whey proteins. Nutr Res 8, 853-864 